\title{
Wood chip denitrification bioreactors can reduce nitrate in tile drainage
}

by Tim Hartz, Richard Smith, Mike Cahn, Thomas Bottoms, Sebastian Castro Bustamante, Laura Tourte, Kenneth Johnson and Luke Coletti

Widespread contamination of surface water with nitrate-nitrogen $\left(\mathrm{NO}_{3}-\mathrm{N}\right)$ has led to increasing regulatory pressure to minimize $\mathrm{NO}_{3}-\mathrm{N}$ release from agricultural operations. We evaluated the use of wood chip denitrification bioreactors to remove $\mathrm{NO}_{3}-\mathrm{N}$ from tile drain effluent on two vegetable farms in Monterey County. Across several years of operation, denitrification in the bioreactors reduced $\mathrm{NO}_{3}-\mathrm{N}$ concentration by an average of 8 to 10 milligrams per liter $\left(\mathrm{mg} \mathrm{L}^{-1}\right)$ per day during the summer and approximately $5 \mathrm{mg} \mathrm{L}^{-1}$ per day in winter. However, due to the high $\mathrm{NO}_{3}-\mathrm{N}$ concentration in the tile drainage (60 to $190 \mathrm{mg} \mathrm{L}^{-1}$ ), water discharged from the bioreactors still contained $\mathrm{NO}_{3}-\mathrm{N}$ far above the regulatory target of $<10 \mathrm{mg} \mathrm{L}^{-1}$. Carbon enrichment (applying soluble carbon to stimulate denitrifying bacteria) using methanol as the carbon source substantially increased denitrification, both in laboratory experiments and in the on-farm bioreactors. Using a carbon enrichment system in which methanol was proportionally injected based on tile drainage $\mathrm{NO}_{3}-\mathrm{N}$ concentration allowed nearly complete $\mathrm{NO}_{3}-\mathrm{N}$ removal with minimal adverse environmental effects.

$\mathrm{R}$ elease of nitrogen $(\mathrm{N})$ from agricultural fields, primarily in nitrate $\left(\mathrm{NO}_{3}{ }^{-}\right)$form, is a significant surface water quality concern across the United States. This problem is particularly acute in the Salinas and Pajaro Valleys of central

Online: https://doi.org/10.3733/ca.2017a0007 coastal California. Vegetable crops such as lettuce and broccoli dominate production, representing approximately $80 \%$ of the irrigated acreage, with fields typically producing two or three crops per year. High crop value and exacting market standards for product size and color provide incentives for heavy fertilization.
Given the sensitivity of these crops to water stress and soil salinity, irrigation is applied frequently, often with a substantial leaching fraction to minimize salt buildup. The production intensity and widespread use of tile drain systems to improve farm productivity have contributed to significant $\mathrm{NO}_{3}-\mathrm{N}$ impairment of surface water in this region. Los Huertos et al. (2001) reported that drainage ditches receiving discharge from tile drain systems commonly had $\mathrm{NO}_{3}-\mathrm{N}$ concentrations exceeding $70 \mathrm{mg} \mathrm{L}^{-1}$.

U.S. Environmental Protection Agency nutrient total maximum daily load (TMDL) regulatory processes are underway to limit $\mathrm{NO}_{3}-\mathrm{N}$ loading in both the Salinas and Pajaro River watersheds. The TMDL surface water $\mathrm{NO}_{3}-\mathrm{N}$ target concentration in the lower Salinas River Basin ranges from the federal drinking water standard of $10 \mathrm{mg} \mathrm{L}^{-1}$ down to $1.4 \mathrm{mg} \mathrm{L}^{-1}$, depending on location and season.

Extensive research has been conducted on fertilizer and irrigation management in the area's vegetable production system, and the potential for significant

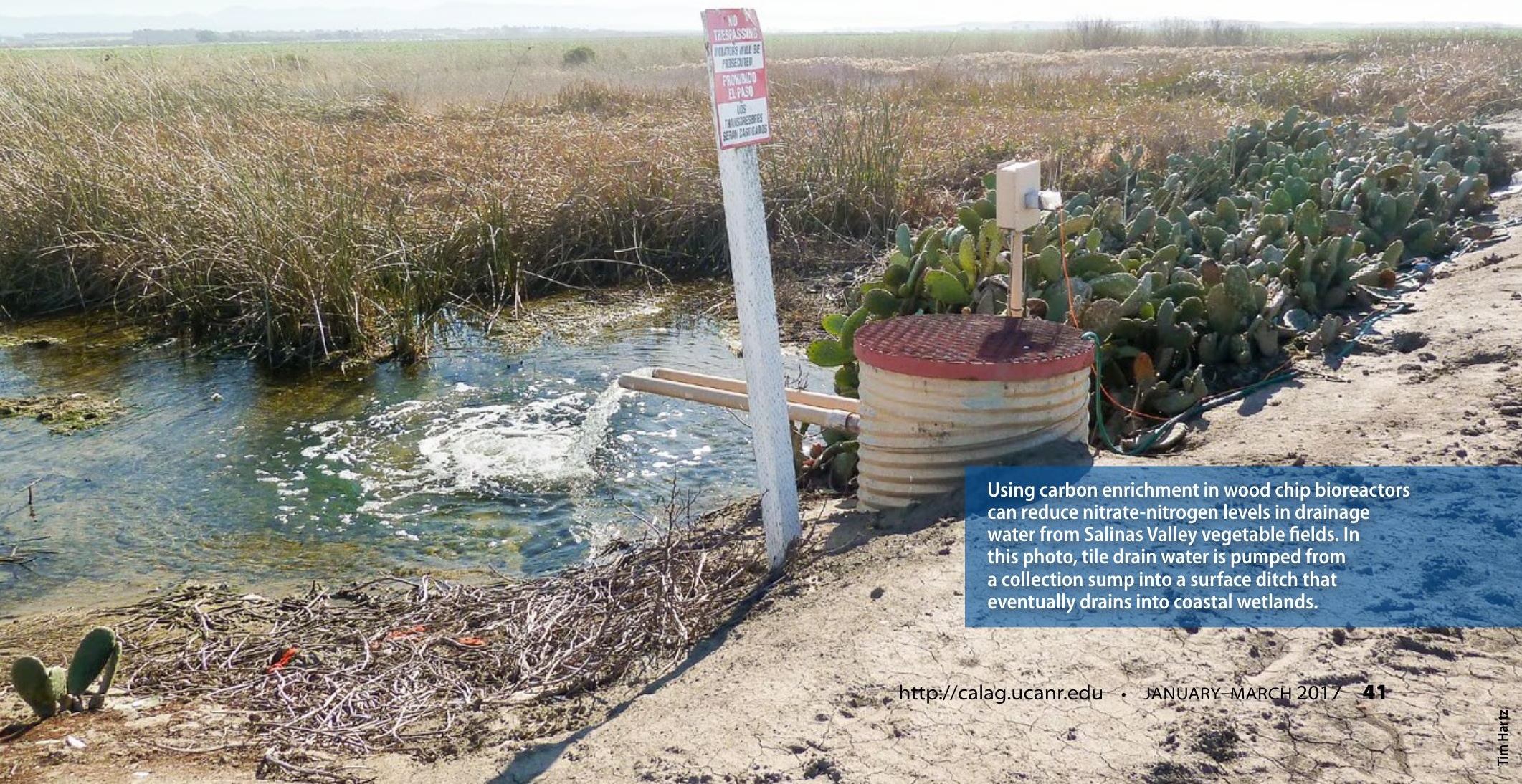




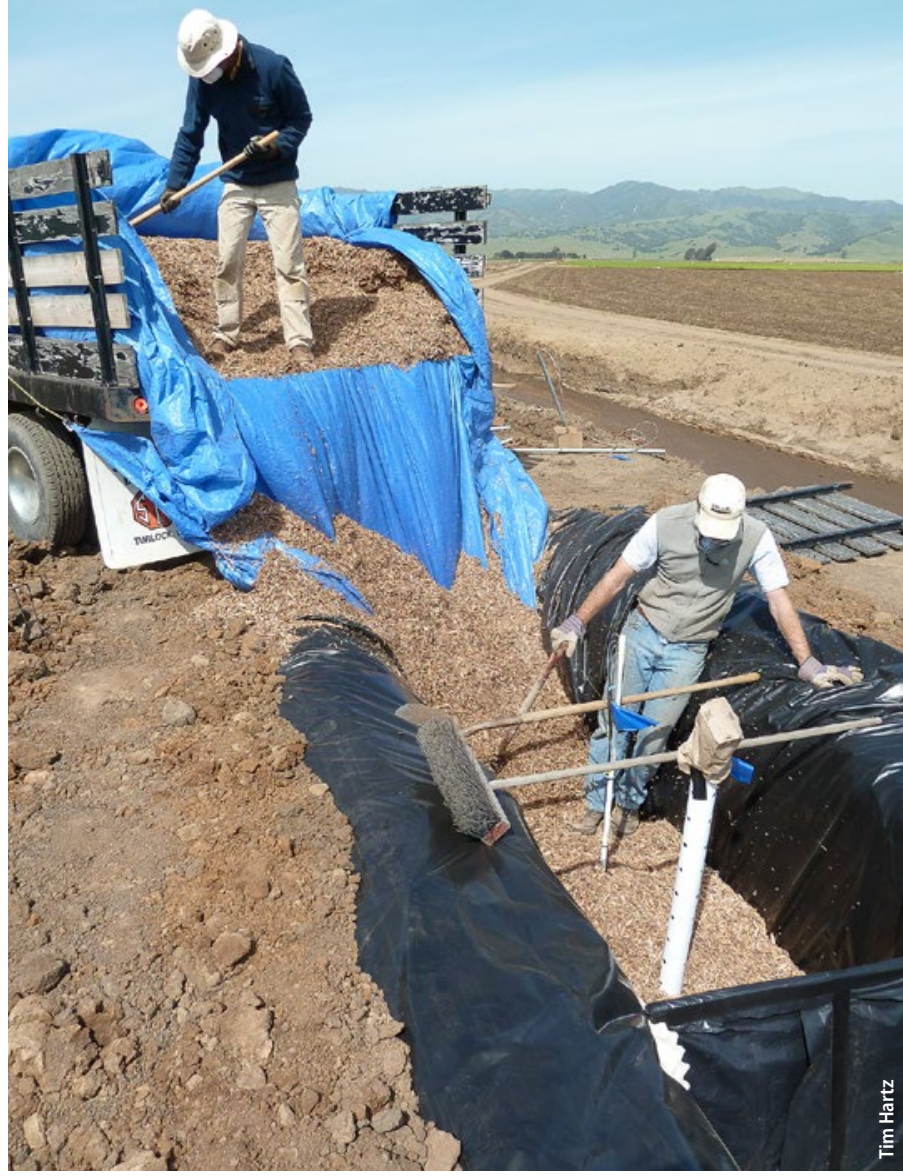

Denitrification bioreactor being filled with wood chips.

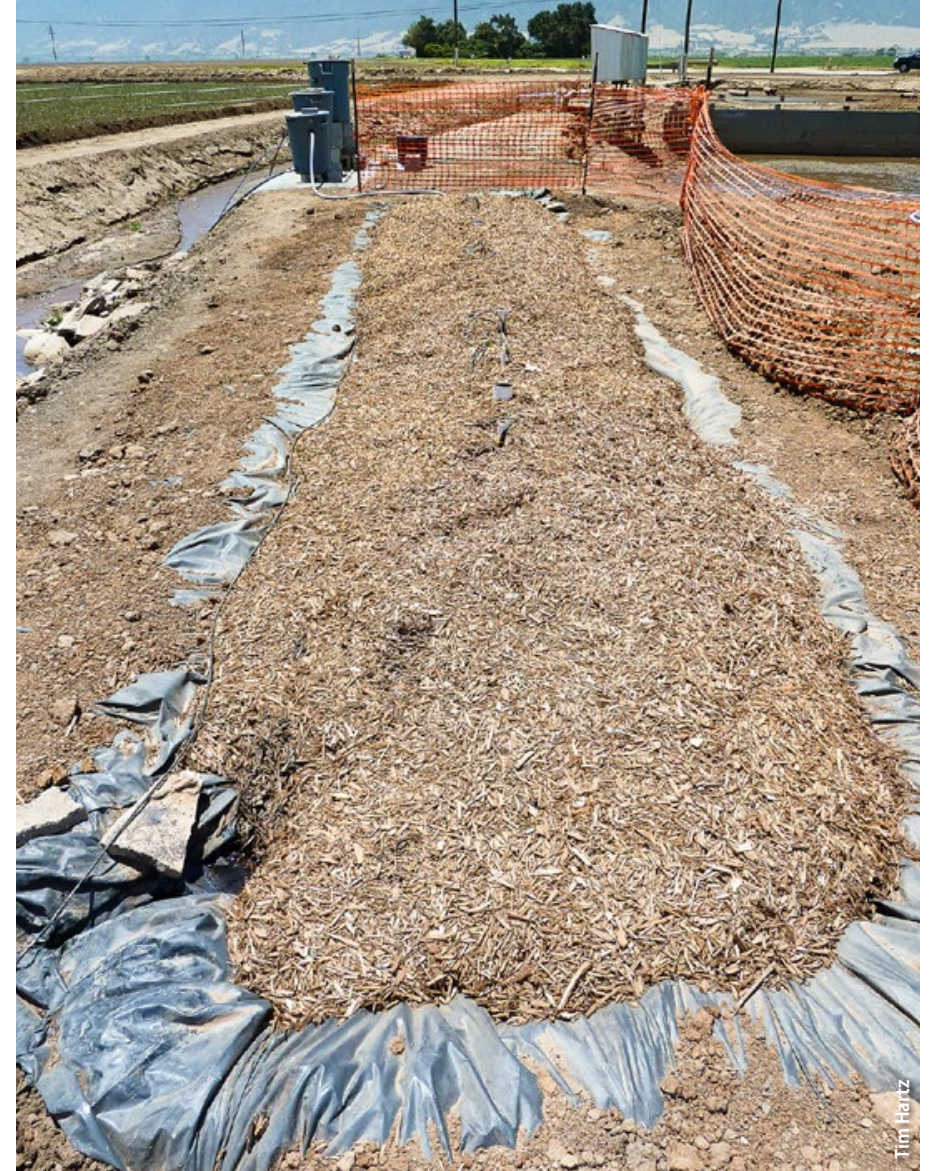

Completed denitrification bioreactor.
Drainage water from the farms' tile drain systems was pumped from collection sumps into the bioreactors at a constant flow rate to achieve approximately 2 days of HRT, based on total water volume. The HRT of free-draining water was undoubtedly less than 2 days, since the water absorbed by the chips was not exchanging as quickly. The water volume entering each bioreactor was recorded using a flowmeter. Water temperature was continuously monitored by thermistors placed in the middle of each bioreactor and 2 feet from the bottom. The water drained by gravity from the bioreactor outlet into surface ditches draining the farms.

The bioreactors were operated without carbon enrichment from their construction in 2011 until fall 2013. Inlet and outlet flows were sampled an average of 2 or 3 times per week during the crop production season (March to October) and once per week during the winter. $\mathrm{NO}_{3}-\mathrm{N}$ was determined on all samples, with nitritenitrogen $\left(\mathrm{NO}_{2}-\mathrm{N}\right.$, a denitrification intermediate) and DOC analyzed periodically. $\mathrm{NO}_{3}-\mathrm{N}$ and $\mathrm{NO}_{2}-\mathrm{N}$ concentrations were determined using the spectrophotometric method of Doane and Horwath (2003). DOC was determined by UV-persulfate oxidation utilizing a Phoenix 8000 analyzer (Teledyne-Tekmar, Mason, $\mathrm{OH}$ ) after filtration through $0.30-\mu \mathrm{m}$ glass fiber filters.

\section{Carbon enrichment studies}

In 2014, six laboratory-scale bioreactors of approximately 0.5 cubic feet (14 liters) were fabricated using PVC pipe. These bioreactors were filled with aged wood chips collected from the field bioreactors. They were installed on the UC Davis campus in a temperature-controlled room maintained at $62^{\circ} \mathrm{F}\left(17^{\circ} \mathrm{C}\right)$ to simulate the summer temperature of tile drainage in the field bioreactors. Peristaltic pumps continuously supplied $\mathrm{NO}_{3}-\mathrm{N}$ solution to maintain a 2-day HRT (based on total water volume), also simulating the operation of the field bioreactors.

Two of the bioreactors received only $\mathrm{NO}_{3}-\mathrm{N}$ solution (no C enrichment), while the others received that same solution augmented by $C$ from either methanol or glycerin (two bioreactors for each C source). These $C$ sources were selected based on their use in the denitrification step of municipal wastewater treatment and the modest cost per unit of $C$. Evaluation of $\mathrm{C}$ enrichment effects on denitrification rate began following a 10-day acclimation period to ensure the development of a bacterial population capable of metabolizing the $\mathrm{C}$ source; similarly, when $\mathrm{C}$ enrichment levels were changed, there was a 10-day acclimation period before evaluation.

The effect of $C$ enrichment on denitrification was evaluated over the range of 40 to $100 \mathrm{mg} \mathrm{L}^{-1} \mathrm{C}$ for methanol and 100 to $150 \mathrm{mg} \mathrm{L}^{-1} \mathrm{C}$ for glycerin. Daily samples were collected on 6 to 8 different days for each level of $\mathrm{C}$ enrichment, with $\mathrm{NO}_{3}-\mathrm{N}$ concentration determined as previously described. Carbon enrichment effects were calculated as the reduction in $\mathrm{NO}_{3}-\mathrm{N}$ concentration beyond that observed in the control (unenriched) bioreactors.

A subsequent laboratory experiment investigated the feasibility of achieving complete denitrification of high-nitrate water using $\mathrm{C}$ enrichment. An inlet $\mathrm{NO}_{3}-\mathrm{N}$ concentration of $160 \mathrm{mg} \mathrm{L}^{-1}$ and an HRT of 2 days were maintained throughout the study to simulate conditions at the site 1 bioreactor. Two levels of $C$ enrichment were evaluated for each $\mathrm{C}$ source (120 and $230 \mathrm{mg} \mathrm{L}^{-1} \mathrm{C}$ from methanol and 160 and $320 \mathrm{mg} \mathrm{L}^{-1} \mathrm{C}$ from glycerin); the higher levels were chosen to be adequate, based on the initial laboratory results, to allow complete denitrification. Each level of $C$ enrichment was evaluated over a 5-week period, with samples collected 
on 25 days for $\mathrm{NO}_{3}-\mathrm{N}$ and $\mathrm{NO}_{2}-\mathrm{N}$ determination.

$\mathrm{N}_{2} \mathrm{O}$ emission from the laboratory bioreactors was also measured. Measurements were made on 2 days for each combination of $C$ source and concentration. Bioreactors were sealed with an airtight PVC cap, and air was circulated through the headspace of the bioreactors at a constant rate of approximately one air exchange every 2 minutes. After an hour of calibration, four headspace air samples were collected 15 minutes apart via needle and syringe and stored in evacuated glass tubes until analysis by gas chromatography.

Matching samples of outlet water were gathered for determination of dissolved $\mathrm{N}_{2} \mathrm{O}$. The water samples were injected into sealed glass tubes containing $2 \mathrm{M} \mathrm{NaOH}$ to stop biological activity in the water. After 24 hours of equilibration, to allow dissolved $\mathrm{N}_{2} \mathrm{O}$ to come to equilibrium with the air in the tube, the headspace in these tubes was resampled and stored in evacuated glass tubes until analysis by gas chromatography.

The effect of $C$ enrichment on the performance of the site 1 bioreactor was evaluated in 2015. Only methanol was evaluated in the field because of its higher efficiency (lower C:N denitrification ratio) than glycerin and our observation that the high viscosity of glycerin complicated its handling and use. Methanol was injected at a constant rate of $140 \mathrm{mg} \mathrm{L}^{-1} \mathrm{C}$ from April 22 until May 5 to ensure establishment of bacteria capable of metabolizing methanol. The $\mathrm{C}$ injection rate was increased to $270 \mathrm{mg} \mathrm{L}^{-1}$ on May 5 and maintained at that level through June 17. Inlet and outlet samples were collected on 12 days during this period and analyzed for both $\mathrm{NO}_{3}-\mathrm{N}$ and $\mathrm{NO}_{2}-\mathrm{N}$; DOC concentration was determined on 5 of those days.

On July 17, an optical nitrate sensor, an in-situ ultraviolet spectrophotometer (ISUS; Johnson and Coletti 2002), was installed at site 1 . This sensor, designed and constructed by scientists at the Monterey Bay Aquarium Research Institute, allowed real-time $\mathrm{NO}_{3}-\mathrm{N}$ monitoring of the tile drainage. ISUS sensors and the related SUNA (submersible UV nitrate analyzer) sensor have been shown to provide accurate $\mathrm{NO}_{3}-\mathrm{N}$ determination in a variety of ground and surface waters (Pellerin et al. 2013; Sackmann 2011).

A C enrichment system was developed in which methanol was injected proportionally to the inlet $\mathrm{NO}_{3}-\mathrm{N}$ concentration at a ratio of approximately 1.4:1 (C:N, on a mass basis), the ratio suggested by the laboratory experiments as being adequate to allow complete denitrification. Inlet $\mathrm{NO}_{3}-\mathrm{N}$ concentration was determined by the ISUS sensor every 15 minutes, with that value determining the methanol injection rate.

This C enrichment system operated from Aug. 15 through Oct. 6, 2015. Inlet and outlet $\mathrm{NO}_{3}-\mathrm{N}$ and $\mathrm{NO}_{2}-\mathrm{N}$ concentrations were determined on samples collected on 14 days during this period, with DOC measured on 6 days. On each of 4 days, four replicate samples of outlet water were collected 15 minutes apart for measurement of dissolved $\mathrm{N}_{2} \mathrm{O}$. The water flow rate was increased on Sept. 17 to reduce HRT to 1.7 days; this flow rate was maintained through Oct. 6.

\section{Field bioreactors reduce $\mathrm{NO}_{3}-\mathrm{N}$}

Denitrification began at both sites within days of the initial filling of the bioreactors. Denitrifying bacteria are ubiquitous, and seeding of inoculum was not necessary. Water temperature in the bioreactors averaged approximately $62^{\circ} \mathrm{F}\left(17^{\circ} \mathrm{C}\right)$ during the summer and $55^{\circ} \mathrm{F}\left(13^{\circ} \mathrm{C}\right)$ during the winter (fig. 1); the water temperature pattern was consistent across years.

Inlet water typically ranged between 5 and $10 \mathrm{mg} \mathrm{L}^{-1}$ DOC. A high level of DOC was present initially in bioreactor effluent, but it declined to $<20 \mathrm{mg} \mathrm{L}^{-1}$ after several weeks of operation (fig. 2). After the first summer season of operation, outlet DOC stabilized between 10 and $15 \mathrm{mg} \mathrm{L}^{-1}$. Bioreactor effluent was also dark colored for the first several weeks of operation, undoubtedly due to tannins leached from the wood chips. To minimize any adverse environmental effects arising from bioreactor start-up, the effluent from the initial weeks of operation might best be applied on fallow ground as pre-irrigation. Because the salinity of tile drainage can be high (it ranged from 2 to $5 \mathrm{dS} \mathrm{m}^{-1}$ at sites 1 and 2), blending with a higher-quality water source may be required.

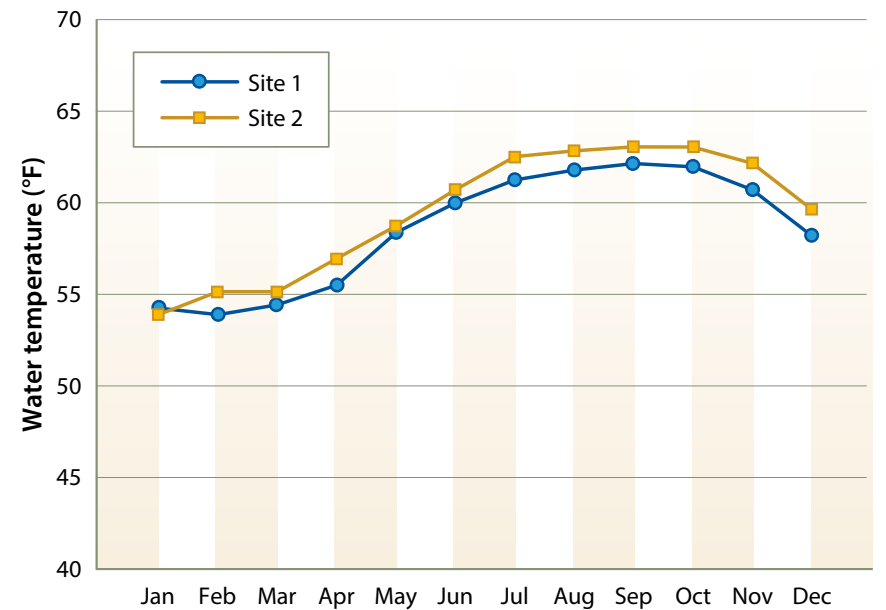

Fig. 1. Monthly mean water temperature in the bioreactors from January through December 2012.

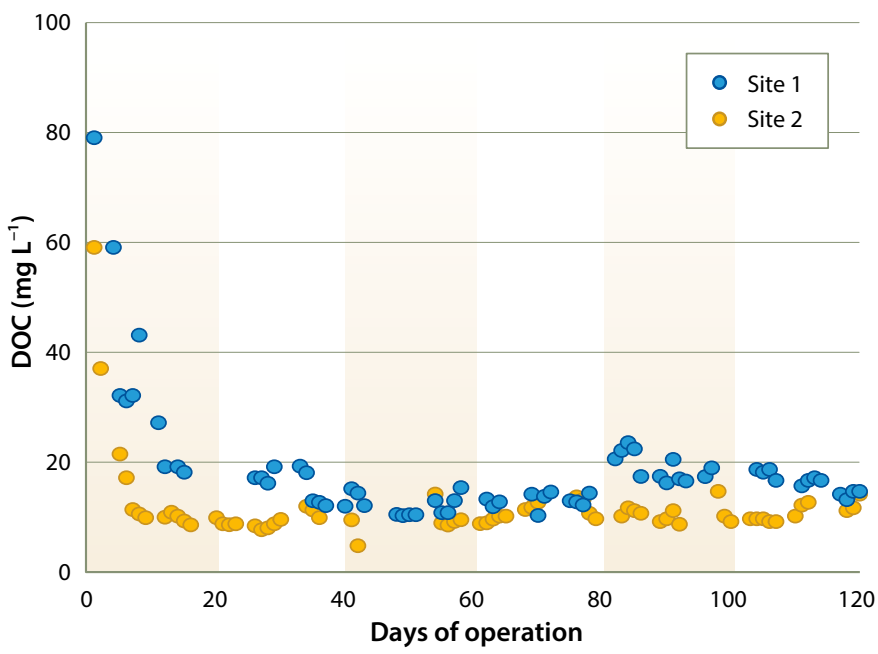

Fig. 2. Dissolved organic carbon (DOC) in bioreactor effluent in the initial 4 months of bioreactor operation. 
Tile drain effluent had consistently high $\mathrm{NO}_{3}-\mathrm{N}$ concentration, ranging between 100 and $180 \mathrm{mg} \mathrm{L}^{-1}$ at site 1 , and 60 and $120 \mathrm{mg} \mathrm{L}^{-1}$ at site 2 (fig. 3). There was no clear seasonal $\mathrm{NO}_{3}-\mathrm{N}$ trend. Denitrification rates were quite consistent between sites and across years. During the summer, $\mathrm{NO}_{3}-\mathrm{N}$ concentration declined by an average of 8 to 10 $\mathrm{mg} \mathrm{L}^{-1}$ per day of HRT (equivalent to approximately 6.4 to $8.0 \mathrm{~g} \mathrm{~N}$ denitrified per cubic meter of bioreactor volume per day of HRT, fig. 4). Denitrification slowed during the winter, undoubtedly due to lower water temperature; $\mathrm{NO}_{3}-\mathrm{N}$ decreased by an average of approximately $5 \mathrm{mg} \mathrm{L}^{-1}$ per day of HRT from November through March.

At both sites, tile drainage $\mathrm{NO}_{2}-\mathrm{N}$ was typically $<0.2 \mathrm{mg} \mathrm{L}^{-1}$. In the initial months of operation in 2011, bioreactor treatment increased $\mathrm{NO}_{2}-\mathrm{N}$ concentration by several $\mathrm{mg} \mathrm{L}^{-1}$, but $\mathrm{NO}_{2}-\mathrm{N}$ in bioreactor effluent gradually declined to $<0.3 \mathrm{mg}$ $\mathrm{L}^{-1}$ by that fall and remained below that level thereafter.

The denitrification rate observed during the summer was similar to that reported for a wood chip bioreactor treating a high-nitrate solution discharged from a greenhouse in New Zealand (Schipper, Cameron et al. 2010; Warneke et al. 2010) and higher than reported from sites treating water with lower $\mathrm{NO}_{3}-\mathrm{N}$ (Schipper, Robertson et al. 2010). However, due to the high $\mathrm{NO}_{3}-\mathrm{N}$ concentration of the tile drainage at these sites, water leaving the bioreactors after 2 days of HRT was

\begin{tabular}{|c|c|c|c|c|c|c|}
\hline \multirow[b]{2}{*}{ Treatment } & \multicolumn{2}{|c|}{ Inlet (mg L $\left.{ }^{-1}\right)$} & \multicolumn{2}{|c|}{ Outlet $\left(\mathrm{mg} \mathrm{L}^{-1}\right)^{*}$} & \multicolumn{2}{|c|}{$\mathrm{N}_{2} \mathrm{O}$ released (\% of denitrified $\mathrm{N} \dagger$ ) } \\
\hline & $\mathrm{NO}_{3}-\mathrm{N}$ & Carbon & $\mathrm{NO}_{3}-\mathrm{N}$ & $\mathrm{NO}_{2}-\mathrm{N}$ & Gaseous $\mathrm{N}_{2} \mathrm{O}$ & Dissolved $\mathrm{N}_{2} \mathrm{O}$ \\
\hline Control & 160 & Unenriched & $151 \pm 1 \neq$ & $<1$ & $0.6 \pm 0.2$ & $11.9 \pm 1.8$ \\
\hline \multirow[t]{2}{*}{ Methanol } & 160 & 120 & $34 \pm 2$ & $8 \pm 0.4$ & $1.6 \pm 0.1$ & $6.5 \pm 0.8$ \\
\hline & 160 & 230 & $<1$ & $<1$ & $1.2 \pm 0.1$ & $<0.1$ \\
\hline \multirow[t]{2}{*}{ Glycerin } & 160 & 160 & $44 \pm 3$ & $3 \pm 0.2$ & $1.0 \pm 0.2$ & $11.9 \pm 0.9$ \\
\hline & 160 & 320 & $<1$ & $<1$ & $1.0 \pm 0.4$ & $0.4 \pm 0.1$ \\
\hline
\end{tabular}

* $\mathrm{NO}_{3}-\mathrm{N}$ and $\mathrm{NO}_{2}-\mathrm{N}$ concentrations are the means of two replicate columns over 25 days of sampling for each $\mathrm{C}$ source/ $\mathrm{C}$ concentration combination.

+ $\mathrm{N}_{2} \mathrm{O}$ values represent the means of eight replicate measurements across 2 days of sample collection for each $\mathrm{C}$ source/ $\mathrm{C}$ concentration combination.

$\ddagger \pm$ numbers indicate the standard error of measurement.

often still above $100 \mathrm{mg} \mathrm{L}^{-1}$. To reach an environmentally acceptable $\mathrm{NO}_{3}-\mathrm{N}$ level, bioreactor treatment would have to be extended for many days, or much more rapid denitrification achieved.

We found it necessary to annually apply new wood chips at a rate of about $10 \%$ of the bioreactor volume to maintain the chip level. Most of the wood chip degradation undoubtedly occurred at the saturated/unsaturated interface, because wood chip half-life in the saturated zone has been reported to be $>30$ years (Moorman et al. 2010). Chip degradation could be significantly reduced by installing an impermeable cover to separate the saturated and unsaturated zones.

\section{C enrichment removes most $\mathrm{NO}_{3}-\mathrm{N}$}

Results from the laboratory studies confirmed that the wood chips were carbon-limited and that $C$ enrichment dramatically increased denitrification rate. Across the range of $C$ concentrations evaluated, there was a stable stoichiometric ratio between $C$ enrichment and denitrification rate. That ratio was approximately 1.4:1 (C applied : N denitrified, on a mass basis) for methanol and 2.0:1 for glycerin. When $C$ was provided at these ratios, nearly complete removal of $160 \mathrm{mg}$ $\mathrm{L}^{-1} \mathrm{NO}_{3}-\mathrm{N}$ was achieved within 2 days of HRT (table 1).

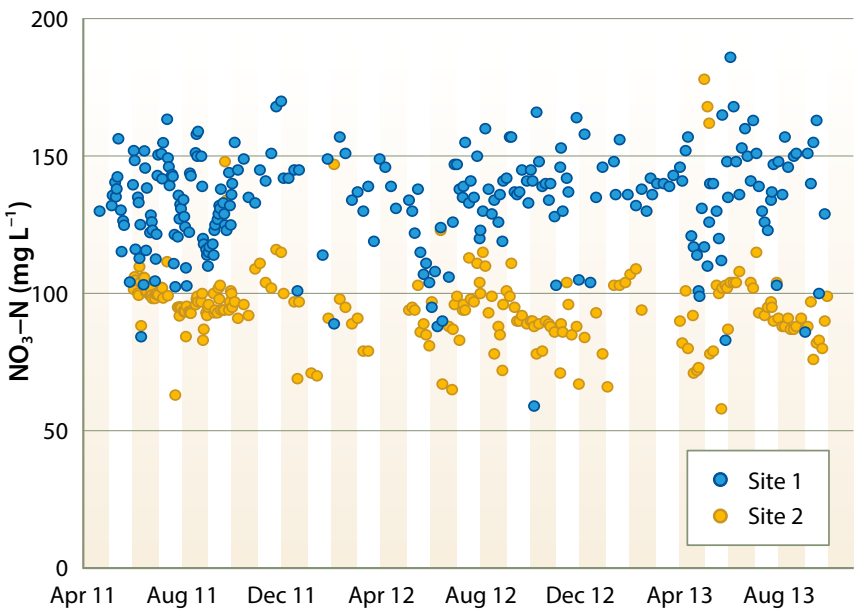

Fig. 3. $\mathrm{NO}_{3}-\mathrm{N}$ concentration in tile drainage entering the bioreactors, 2011-2013.

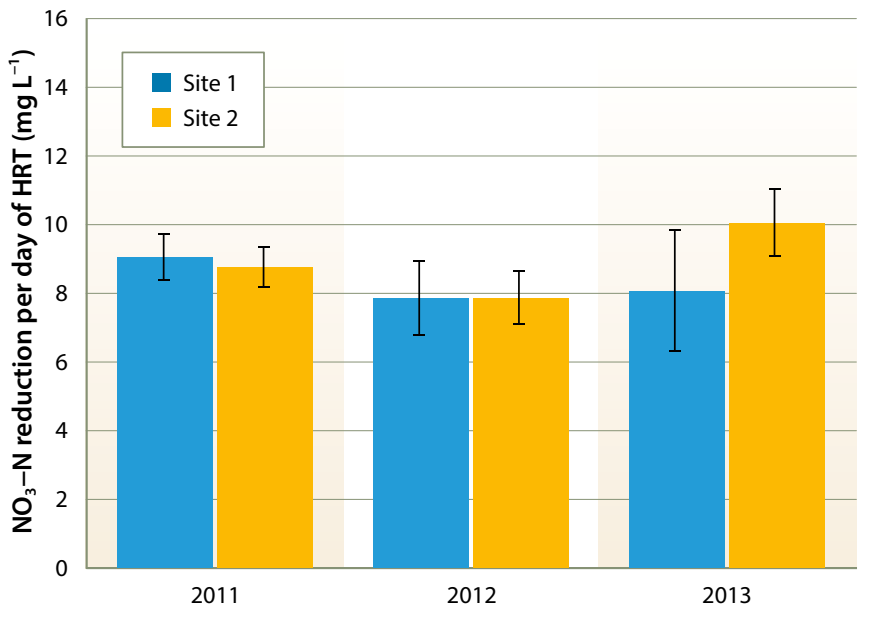

Fig. 4. Mean summer (June to September) denitrification rates achieved per day of hydraulic residence time (HRT); bars indicate standard error of measurement. 
At lower levels of $\mathrm{C}$ enrichment, significant amounts of $\mathrm{NO}_{2}-\mathrm{N}$ and $\mathrm{N}_{2} \mathrm{O}$ were present in outlet water, signaling incomplete denitrification. In the unenriched control bioreactors, gaseous $\mathrm{N}_{2} \mathrm{O}$ release was slight, but dissolved $\mathrm{N}_{2} \mathrm{O}$ release in outlet water was substantial (when expressed as a percentage of denitrified
$\mathrm{N})$. A low level of $\mathrm{C}$ enrichment resulted in gaseous and dissolved $\mathrm{N} 2 \mathrm{O}$ release as high as $1.6 \%$ and $11.9 \%$ of denitrified $\mathrm{N}$, respectively. However, gaseous $\mathrm{N}_{2} \mathrm{O}$ release was reduced and dissolved $\mathrm{N}_{2} \mathrm{O}$ release nearly eliminated when C enrichment was sufficient to complete denitrification.

\section{From May 5 through June 17, 2015, inlet $\mathrm{NO}_{3}$-N averaged $170 \mathrm{mg} \mathrm{L}^{-1}$, varying from 150 to $193 \mathrm{mg} \mathrm{L}^{-1}$. Outlet water $\mathrm{NO}_{3}-\mathrm{N}$ was consistently below $1 \mathrm{mg} \mathrm{L}^{-1}$, with no measureable $\mathrm{NO}_{2}-\mathrm{N}$.}
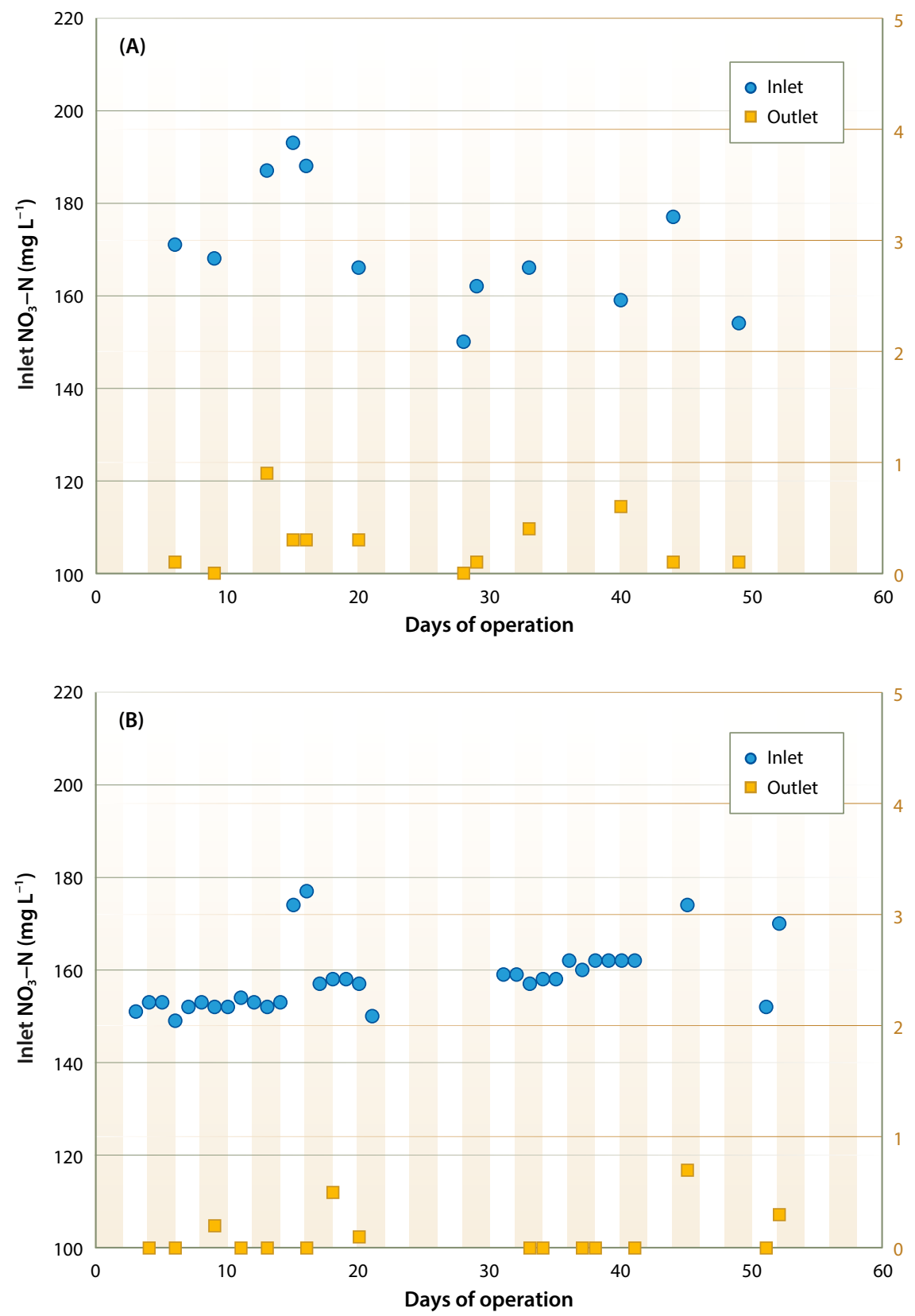

Fig. 5. Effect of carbon enrichment on bioreactor outlet $\mathrm{NO}_{3}-\mathrm{N}\left(\mathrm{mg} \mathrm{L}^{-1}\right)$ at site 1 ; constant enrichment of $270 \mathrm{mg} \mathrm{L}^{-1} \mathrm{C}(\mathrm{A})$, and proportional enrichment at a C:N ratio of 1.4:1 in inlet water (B).

C enrichment using methanol dramatically increased denitrification rate at the site 1 bioreactor. Constant enrichment at $270 \mathrm{mg} \mathrm{L}^{-1} \mathrm{C}$ resulted in nearly complete denitrification (fig. 5A). From May 5 through June 17, 2015, inlet $\mathrm{NO}_{3}-\mathrm{N}$ averaged $170 \mathrm{mg} \mathrm{L}^{-1}$, varying from 150 to $193 \mathrm{mg} \mathrm{L}^{-1}$. Outlet water $\mathrm{NO}_{3}-\mathrm{N}$ was consistently below $1 \mathrm{mg} \mathrm{L}^{-1}$, with no measureable $\mathrm{NO}_{2}-\mathrm{N}$. DOC in outlet water averaged $41 \mathrm{mg} \mathrm{L}^{-1}$ higher than inlet water across five sampling dates.

Had the bioreactor been operated without $\mathrm{C}$ enrichment, denitrification of approximately $15 \mathrm{mg} \mathrm{L}^{-1} \mathrm{NO}_{3}-\mathrm{N}$ would have been expected, meaning that denitrification of about $155 \mathrm{mg} \mathrm{L}^{-1} \mathrm{~N}$ could be attributed to the enrichment. Therefore, the estimated C:N ratio achieved was

(270 $\mathrm{mg} \mathrm{L}^{-1} \mathrm{C}$ injected $-41 \mathrm{mg} \mathrm{L}^{-1} \mathrm{C}$ in effluent) / $155 \mathrm{mg} \mathrm{L}^{-1} \mathrm{~N}$ denitrified $=1.48 \mathrm{C}: \mathrm{N}$

This result was similar to the 1.4:1 C:N ratio for methanol determined in the laboratory studies.

Controlling $\mathrm{C}$ enrichment based on real-time $\mathrm{NO}_{3}-\mathrm{N}$ monitoring worked well (fig. 5B). Nitrate concentrations reported by the sensor were validated by comparison of sensor values with laboratory determinations on 26 discrete samples of the inlet water; the mean difference was $1 \mathrm{mg}$ $\mathrm{L}^{-1} \mathrm{NO}_{3}-\mathrm{N}$. Across 7 weeks of operation, the ISUS sensor showed that inlet $\mathrm{NO}_{3}-\mathrm{N}$ concentration varied from 57 to $184 \mathrm{mg}$ $\mathrm{L}^{-1}$. Proportionally injecting methanol at a 1.4:1 C:N ratio consistently reduced $\mathrm{NO}_{3}-\mathrm{N}$ in outlet water to $<1 \mathrm{mg} \mathrm{L}^{-1}$.

Dissolved $\mathrm{N}_{2} \mathrm{O}$ in outlet water during the period of proportional $\mathrm{C}$ enrichment represented $<0.1 \%$ of denitrified $\mathrm{N}$, indicating that essentially complete denitrification was achieved. There was undoubtedly significant gaseous $\mathrm{N}_{2} \mathrm{O}$ emission still occurring along the length of the bioreactor, but this could be minimized by covering the bioreactor with a totally impermeable film (TIF), as is commonly used during soil fumigation. The use of a TIF cover would limit gaseous losses as water moves through the bioreactor, allowing sufficient time to complete the reduction of $\mathrm{N}_{2} \mathrm{O}$ to $\mathrm{N}_{2}$.

During the period of proportional $C$ enrichment, outlet water DOC averaged approximately $10 \mathrm{mg} \mathrm{L}^{-1}$ higher than inlet water DOC, confirming that efficient denitrification can be achieved 
with C enrichment without greatly increasing DOC (and the associated increase in biochemical oxygen demand) in discharged water.

\section{Economic feasibility}

Given the high $\mathrm{N}$ load in tile drainage from coastal vegetable farms, a denitrification bioreactor operated in a passive mode (no $\mathrm{C}$ enrichment) would have to be quite large to come close to meeting the environmental target $\mathrm{NO}_{3}-\mathrm{N}$ concentration in discharged water $\left(<10 \mathrm{mg} \mathrm{L}^{-1}\right)$. We estimated the costs of installation, operation and maintenance of a wood chip bioreactor 200 feet long, 55 feet wide and 6 feet deep (61 by 16.8 by 1.8 meters).

This size was calculated to be adequate to achieve a mean discharge water $\mathrm{NO}_{3}-\mathrm{N}$ concentration of $10 \mathrm{mg} \mathrm{L}^{-1}$ during the irrigation season from a 200 -acre (80-hectare) coastal vegetable farm producing 65,000 gallons (250 cubic meters) of tile drainage daily, based on the very conservative assumption that farm management could limit tile drainage $\mathrm{NO}_{3}-\mathrm{N}$ to $60 \mathrm{mg} \mathrm{L}^{-1}$.

Over a projected 10-year life, the total system was estimated to cost (net present value) approximately $\$ 92,000$, or about $\$ 1.50$ per pound ( $\$ 3.30$ per kilogram) of $\mathrm{N}$ denitrified (Hartz et al. 2015). At higher tile drainage $\mathrm{NO}_{3}-\mathrm{N}$ concentrations (like those observed at both field sites), the bioreactor size would have to increase, and in a passive operation mode there would be no way to effectively treat periodic fluctuations in $\mathrm{NO}_{3}-\mathrm{N}$ load.

Carbon enrichment provides a tool for handling fluctuating $\mathrm{N}$ loads, and it can substantially reduce the bioreactor size requirement. Our data suggest that a bioreactor employing $\mathrm{C}$ enrichment could achieve complete denitrification within 1.7 days of HRT, regardless of tile drainage $\mathrm{NO}_{3}-\mathrm{N}$ concentration. Therefore, a bioreactor 100 feet by 30 feet by 6 feet (30.5 by 9.1 by 1.8 meters) should be adequate for a 200 -acre (80-hectare) farm producing 65,000 gallons (250 cubic meters) of drainage water daily.

We estimate the construction and operational costs for such a bioreactor to be approximately $\$ 33,000$ over a 10 -year period. Assuming complete nitrate removal and a mean inlet $\mathrm{NO}_{3}-\mathrm{N}$ concentration of $150 \mathrm{mg} \mathrm{L}^{-1}$ (similar to site 1 ), this expense would equate to approximately $\$ 0.60$ per pound of $\mathrm{N}$ denitrified, exclusive of the costs associated with $C$ enrichment. The cost of methanol fluctuates with the price of oil, but at an estimated bulk price of $\$ 2.50$ to $\$ 3.00$ per gallon ( $\$ 0.66$ to $\$ 0.79$ per liter), methanol would cost approximately $\$ 1.40$ to $\$ 1.70$ per pound ( $\$ 3.10$ to $\$ 3.70$ per kilogram) of $\mathrm{N}$ denitrified. Currently, sensors capable of continuously measuring $\mathrm{NO}_{3}-\mathrm{N}$ concentration are expensive; commercial $\mathrm{NO}_{3}-\mathrm{N}$ sensors based on the ISUS technology are at least $\$ 15,000$. Also, more active management would be required to keep a $\mathrm{C}$ enrichment system operating efficiently than to operate a bioreactor in a passive operation mode.

Clearly, $\mathrm{C}$ enrichment would be more expensive than passive bioreactor operation per unit of $\mathrm{NO}_{3}-\mathrm{N}$ denitrified. However, $\mathrm{C}$ enrichment appears to offer the only practical way to sufficiently treat tile drainage with high but fluctuating $\mathrm{NO}_{3}-\mathrm{N}$ to consistently meet TMDL nitrate targets. Furthermore, the ability to apply C proportionally to $\mathrm{NO}_{3}-\mathrm{N}$ load is critical to efficient $\mathrm{C}$ utilization and to minimize both the emission of $\mathrm{N}_{2} \mathrm{O}$ and dissolved $\mathrm{C}$ in effluent.

Remediating tile drainage using denitrification bioreactors and proportional $C$ enrichment may be a technology more appropriately employed on an area larger than an individual farm. A larger installation could achieve an economy of scale, reducing construction, management and $\mathrm{NO}_{3}-\mathrm{N}$ sensing costs per unit of $\mathrm{N}$ denitrified. CA

T. Hartz is UC Cooperative Extension (UCCE) Specialist in the Department of Plant Sciences at UC Davis; $R$. Smith is UCCE Farm Advisor in Monterey County; M. Cahn is UCCE Farm Advisor in Monterey County; T. Bottoms and S. Castro Bustamante were graduate students in the Department of Plant Sciences at UC Davis; L. Tourte is UCCE Farm Advisor in Santa Cruz County; K. Johnson is Senior Scientist, Monterey Bay Aquarium Research Institute; L. Coletti is Senior Research Technician, Monterey Bay Aquarium Research Institute.

\section{References}

Blowes DW, Robertson WD, Ptacek CJ, Merkley C. 1994 Removal of agricultural nitrate from tile-drainage effluent water using in-line bioreactors. J Contam Hydrol 15:207-21

Bottoms TG, Smith RF, Cahn MD, Hartz TK. 2012. Nitrogen requirements and $\mathrm{N}$ status determination of lettuce. HortScience 47:1768-74.

Breschini SJ, Hartz TK. 2002a. Drip irrigation managemen affects celery yield and quality. HortScience 37:894-7. Breschini SJ, Hartz TK. 2002b. Presidedress soil nitrate testing reduces nitrogen fertilizer use and nitrate leaching hazard in lettuce production. HortScience 37:1061-4

Cameron SG, Schipper LA. 2010. Nitrate removal and hydraulic performance of organic carbon for use in denitrification beds. Ecol Eng 36:1588-95.

Coyne MS. 2008. Biological denitrification. In: Schepers JS, Raun W (eds.). Nitrogen in Agricultural Systems. Monograph 49, American Society of Agronomy, Madison, WI. p 197-249.

Doane TA, Horwath WR. 2003. Spectrophotometric determination of nitrate with a single reagent. Anal Letters 36:2713-22.
Hartz T, Smith R, Cahn M, Tourte L. 2015. Remediation of Tile Drain Water Using Denitrification Bioreactors. CDFA-FREP Final Report. 29 p. www.cdfa.ca.gov/is/ffldrs/ frep/pdfs/completedprojects/11-0462-SA_Hartz.pdf (accessed May 16, 2016).

Johnson KS, Coletti L. 2002. In situ ultraviolet spectrophotometry for high resolution and long-term monitoring of nitrate, bromide and bisulfide in the ocean. Deep-Sea Res Pt I 49:1291-305.

Los Huertos M, Gentry LE, Shennan C. 2001. Land use and stream nitrogen concentrations in agricultural watersheds along the central coast of California. ScientificWorld J 1:615-22.

Moorman TB, Parkin TB, Kaspar TC, Jaynes DB. 2010. Denitrification activity, wood loss, and $\mathrm{N}_{2} \mathrm{O}$ emissions over 9 years from a wood chip bioreactor. Ecol Eng 36:1567-74.

Pellerin BA, Bergamaschi BA, Downing BD, et al. 2013. Optical Techniques for the Determination of Nitrate in Environmental Waters: Guidelines for Instrument Selection, Operation, Deployment, Maintenance, Quality Assurance, and Data Reporting. USGS Techniques and Methods 1-D5. 37 p

Robertson WD, Merkley LC. 2009. In-stream bioreactor for agricultural nitrate treatment. J Environ Qual 38:230-7.
Robertson WD, Ptacek CJ, Brown SJ. 2009. Rates of nitrate and perchlorate removal in a 5-year-old wood particle reactor treating agricultural drainage. Ground Water Monit R 29:87-94.

Sackmann BS. 2011. Deschutes River Continuous Nitrate Monitoring. Washington State Department of Ecology Publication 11-03-030. https://fortress.wa.gov/ecy/ publications/documents/1 103030.pdf (accessed May 16, 2016).

Schipper LA, Cameron SC, Warneke S. 2010. Nitrate removal from three different effluents using large-scale denitrification beds. Ecol Eng 36:1552-7.

Schipper LA, Robertson WD, Gold AJ, et al. 2010. Denitrifying bioreactors - An approach for reducing nitrate loads to receiving waters. Ecol Eng 36:1532-43.

Warneke S, Schipper LA, Bruesewitz DA, et al. 2010. Rates, controls and potential adverse effects of nitrate removal in a denitrification bed. Ecol Eng 37:511-22.

Warneke S, Schipper LA, Matiasek MG, et al. 2011. Nitrate removal, communities of denitrifiers and adverse effects in different carbon substrates for use in denitrification beds. Water Res 45:5463-75. 